\title{
Et sydslesvigsk præstehjem.
}

\author{
Af N. A. Jensen.
}

\section{Indledning.}

Blandt de bøger, der vandt min kærlighed allerede i unge dage og har bevaret den til nu, er "Tre af mine venner". Forfatteren, "den gamle feltpræst" Høyer Møller, blev som helt ung mand udnævnt til feltpræst i 1850, men kom først efter Istedslaget ned til hæren, der længe vedblev at ligge med flere afdelinger langs Danevirke. Høyer Møller fik således lært Sydslesvig godt at kende, når han færdedes fra øst til vest og holdt gudstjeneste for soldaterne i hele 14 forskellige kirker. Siden, da soldaterne kunde føres tilbage fra denne vogterkæde, blev han fast garnisonspræst i Slesvig by med slotskirken på Gottorp som sin kirke. Siden blev han sognepræst i Nordborg (1861-64), derefter feltprovst i $64 \mathrm{og}$ sluttelig præst i Kølstrup ved Kerteminde. Her fordybede den aldrende mand sig i sine ungdomsminder, og her skrev han da de boger, der både ved deres skønne danske sprog og deres varme indhold vil bevare hans navn $i$ et taknemligt folks minde.

Høyer Møller er både digter og historiker. Det forlener hans sprog med en egen fylde og skonhed; man læse blot forordet til »Tre af mine venner": på en gang en hymne til fædrelandets pris og en magtfuld kalden på gamle og unge til dets værn. Han kan i så henseende minde om A. D. Jørgensen. Men følgen er så også, at vi må være forberedt på, at Dichtung er sammensmeltet med Wahrheit $i$ hans skildringer. "Tre af mine venner" er et typisk eksempel på dette. - Den ene ven er oberst Helgesen, Frederiksstads tapre forsvarer i efteråret 1850. Af ham giver Høyer Møller en meget varm, men rent historisk skildring, hvorfor han da også nævner hans navn. Den anden ven er Frederiksstads kongetro og frygtlose borgmester, der vovede det yderste 
mod byens Slesvigholstenere for at holde sin troskab til den danske konge. Men her mærkes en del fri digtning, bl. a. i borgmesterens taler, og forf. markerer dette ved ikke at nævne borgmesterens navn. Han er ellers historisk nok, hed Jan Jelles Schütt, som den Hollænder han var af herkomst, og hans grav findes endnu på Mennoniternes lille kirkegård, og hans prægtige, karakterfaste åsyn kan endnu ses i det lille præsteværelse, der hører til deres kirke. Frederiksstad var jo ligesom Fredericia givet til fristed for de refomerte. Schütt var forøvrigt også medlem af den slesvigske stænderforsamling.

Men den tredje skildring har igen nogle grader mere af digtningens karakter. Det er præstekonen, som "gjorde, hvad hun kunde«. Men Høyer Møller har rigtignok også gjort, hvad han kunde, for at vare sig imod, at den tages som fuld Wahrheit, idet han her fortier både hendes navn, bosted og dødsår, uagtet fortællingen slutter med hendes død og jordfæstelse, og han selv er til stede og holder en lille tale ved graven.

Det er denne tredje - eller i bogen første - skildring, der har grebet mig stærkest; og det er om hende og hendes hjem, her skal fortælles, navnlig om hendes mand, som i fortællingen indtager en meget lille og tilmed urigtig plads.

Jo kærere denne altopofrende kvindeskikkelse blev mig, des mere måtte jeg ønske at kende hendes navn og sted. Men Høyer Møller, som jeg kun havde truffet én gang - det år, jeg selv trådte ind i præstegerningen (1896), og han allerede var trådt ud - døde 1904, før jeg fik spurgt ham. Det blev da til en tyveårig leden og spørgen, indtil jeg i februar 1922 fandt ud til hans datter, enkefru birkedommer Valeur i Hellerup. Fra en skuffe fremtog hun en omhyggelig indbunden pakke "Casualreden 1850-64". Ja, i disse lejlighedstaler må det være, om nogetsteds! Mit hjerte bankede, mine fingre bladrede! Og midt i pakken lå: Rede über die Frau Pastorin Augustiny in Hollingstedt 22. april 1857. Alt på én gang! Hvilken glæde! Jeg fik lov at låne den og oversætte den til Højskolebladet (21. april 22).

Den lyder sådan: 
Også jeg må bringe dig et afskedsord; jeg siger $m$ å, thi længe vilde jeg ikke, fordi jeg ikke er det sprog mægtigt, som var hendes. Og når jeg dog gør det, saa sker det ikke af nogen anden grund end den, at jeg $m$ \&. Det gik mig som profeten Jeremias, når han siger: "Jeg tænkte: jeg vil ikke tale mere; men da blev det som en brændende ild i mit hjerte, så jeg trættedes ved at holde den tilbage og formåede det ikke“. Det gik mig som St. Paul, når han siger: "Om jeg prædiker, tor jeg ikke rose mig deraf, thi jeg $m$ a gøre det«. Således må jeg også tale her, jeg nødes dertil, og det ud af kærlighed, af taknemlighed.

Ja, du kære, trofaste moder! Hvad du har været for dine egne, det ved vi alle. Jeg kommer $i$ fleres navn og siger dig tak for alt godt, du har gjort mod de fremmede. Vi har ikke forglemt, da dit hus var fuldt, men dit hjerte ikke [j: hun ønskede endnu flere $i$ indkvartering]. Vi har ikke forglemt din møje og dit arbejde ved dag og ved nat. Forglemt! Oh hvorledes skal vi kunne forglemme det, vi, for hvis skyld du tålte så megen uro og besvær! - Ja, hvorledes kan vi forglemme, at du, som ikke kunde falde på slagmarken, dog fik den forste begyndelse til denne sygdom i hine urolige dage. Jeg ved det vel, overfor Gud bliver du som vi alle ikke frikendt ved, hvad du øved, men uden fortjeneste af hans náde ved den forløsning, som er sket ved Jesus Kristus. Men jeg kendte også din tro, véd, hvorledes alt dit værk kom af din tro og desårsag var Gud velbehageligt. $\mathrm{Og}$ for disse kærlighedsfulde gerninger mod os siger jeg dig i mit eget og alle mine venners navn vor tak.

Jeg takker dig, thi du var os moder og saster, da vi ikke havde dem hos os her. Jeg takker dig for hver gang, du stod i dit huses dør og bød os velkommen. Jeg siger dig tak for dit milde øje, for hvert hjerteligt ord, når vi skiltes fra dig. Ja. kære, trofaste frue, tak for alt det, som vi ikke kan gengælde dig! Den kære, harmhjertige Gud gengælde dig det! Amen! - - -

$\rightarrow$ Så er fortællingen altså ikke digtning alene, der står en virkelig kvinde bag den som dens midtpunkt. Og her turde det så være på tide at give et kort rids af dens indhold: Som feltpræst kommer Høyer Møller til hendes by. En dansk major, indkvarteret hos hende, gør præsten opmærksom på hende som et næsten gådefuldt menneske, for så vidt hun opofrer sig for sin store indkvartering af både officerer og menige langt ud over, hvad hendes svage kræfter formår at holde til, og som dog ikke vil høre tale om at skåne sig, ja bliver helt ulykkelig, når majoren taler derom. Hendes kvindelige hjælpere er rendt af frygt for de fale danske, hun er alene om huset, mand, 4 
børn og de indkvarterede, og det synes dog, som om det vilde være hende en sjælelig ulykke, om dette toges fra hende.

Dette vækker præstens interesse, og han gør sig ærind i præstegården for at lære familien at kende. Om hendes mand fortælles kun lidt. Han viser sig at være en meget høflig og elskværdig mand, der gør sig umage med at tale dansk, spørger, om feltpræsten ønsker at "gå efter stuen eller sidde på min løve" (Laube, lysthus); ligesom han ved senere lejlighed, da H. M. ser en af hans drenge, udtaler håbet om, at han engang som dansk soldat kan blive "fløjelsmand" (fløjmand), stor som han er af sin alder.

Det er fruen, vi horer så langt mere om. H. M. bliver som majoren betaget af hendes gådefulde trang til at opofre sig udover alle kræfters grænse, men aner tillige af en egen uro, der fylder hende, at der er en bestemt tung årsag dertil. Den skimtes, da hun en dag kommer til at robe, at hun i religiøs henseende lever på den tanke, at man kan og skal opveje eller udslette, hvad man har gjort ilde, ved efterfølgende gode gærninger. Hun anfører bl. a. Zakkæus som et bibelsk eksempel derpå. Feltpræsten må sige hende alvorligt imod: "Det er denne vildfarelse om vor egen ævne til at gøre noget godt igen, der avler den store selvretfærdighed og letsindighed, som tilsidst ender med selv at tage æren for udslettelsen af vore synder $i$ stedet for at lade ham, hvem den ene tilkommer, beholde den. Tro mig, det er alle disse falske veksler, som så mange daglig går og udsteder på sig selv, der forhindrer dem fra at komme til ham, der har udslettet hele vort gældsbrev«.

Denne imødegåelse piner den samvittighedsfulde kvinde, idet den rokker det grundlag, hun lever på, og dog ikke synes at kunne hjælpe hende over på et andet, føre hende fra det rationalistiske til det ægte kristensyn på vort livsvilkår. Ikke foreløbig da. Men sandheds tale, sået $i$ et hjærte, som inderst inde er af sandheden, bryder sig dog altid vej og bærer en dag sin frugt.

Men hvad var så det, hun formentlig havde gjort ilde og nu 
så dybt, men tillige så håbløst prøvede at gøre godt igen? Det fik H. M. forst senere at vide. Han kom en dag for at holde altergang for soldaterne. Hun og hendes mand bad om lov at komme med, skønt de - i følge fortællingen - kun forstod meget lidt dansk. Selvfelgelig fik de lov. Og bagefter holdt hun så hjemme i dagligstuen skriftetalen, der bekendte hendes sinds - nu overvundne - dybe uro. Lad hendes egne ord, kort gengivne, fortælle det:

Jeg er datter af en loyal officer, hørte trods tysk sprog kun kongetro tale i mit hjem; blev forlovet 16 år, gift 18 år gl. og kom med min mand til en af de små Halliger, hvor vi levede fattigt, men lykkeligt, indtil en badegæst fra Før under besøg hos os fik medlidenhed med vor ensomhed og sendte os en mængde bøger, deriblandt desværre også skrifter af »slesvigholstensk " art, der fyldte os med de giftige anskuelser, der siden skulde føre til oprøret. Da vi omsider flyttede her til, fik vi disse tanker på nært hold i vor ny menighed. Og da $1848 \mathrm{kom}$, og provsten sammenkaldte præsterne for at bede dem underskrive en erklæring om det umulige i længere at adlyde den danske øvrighed, skrev min mand under, og jeg tilskyndede ham dertil ud af en frygt, jeg ikke selv forstod, da jeg dog ellors ikke er bange, ja havde oplevet de voldsomste uvejr på den lille Hallig, hvor vandet fyldte vore stuer, så vi måtte søge op på loftet, men uden at jeg et øjeblik havde mistet freden og frimodigheden i mit hjærte. - Men siden denne dag, hvor vi gik ind paa den falske vej, frygtende mennesker mere end vor Gud og konge, forlod freden mig. Jeg havde gjort ilde, og så måtte jeg prøve at gøre det godt igen. Sådan havde jeg det, da De kom og viste mig det umulige deri; klarede for mig, hvad jeg i grunden dog godt havde vidst, at der kun var én, der havde gjort alting godt; og nu trængte jeg så usigelig til at komme til ham, ikke ad følelsens bedragelige, men ad sacramentets ubedragelige vej; og nu forstaar De, hvorfor det da blev mig så meget om at gøre at komme til Herrens bord. Jeg så, at hvad jeg havde gjort mod soldaterne, var ikke gjort af kærlighed, men af frygt som afbe- 
taling af en gæld; men hvad der ikke oves af kærlighed, er jo uskikket dertil, ja er intet værd. Men nu, da det kan øves ud af det retvendte syn og sind, forstår De, at jeg ikke vil miste nogen lejlighed til fortsat at tjene min frelser og mit folk. De har hjulpet mig af med en vildfarelse, men De må ikke berøve mig min glæde; ti nu går jeg så let og frejdigt til det altsammen imod før.

- Hun fortsatte da også, så længe der var soldater i egnen. Men kræfterne var små, og i de følgende, roligere år ældedes hun meget og bukkede tilsidst under. Den sidste tjeneste, H. M. kunde gøre hende, var at formå hendes slesvigholstenske broder. til at besøge hende og blive udsonet med hjemmet. Hun døde med hans og sin mands hænder i sine. - Fortællingen om denne kvinde, der havde villet bære mere, end et menneske kan bære, men også lært at lægge byrden på skuldrene af en, som er stærkere, slutter således:

"Majoren og jeg fulgtes ad fra graven; da han spurgte: Dersom vi sætter en sten på hendes grav, hvad skal der så stå på den? svarede jeg: Mener De ikke, vi bør sætte:

Hun gjorde, hvad hun kunde!

Sie hat gethan, was sie konnte!« -

Ja, sådan er billedet, kort gengivet. $O g$ nảr vi så sammenholder det med ligtalen, jeg fandt 65 år efter, bliver 2 ting tydelige: Talen stemmer $\mathbf{i}$ sin sammenfattende korthed såre vel med billedet; men når $H$. M. kunde så lidt tysk, som han selv dær siger, må billedet dog også være en frihåndstegning; navnlig kan deres samtaler og især hendes lange "skriftetale" kun være meget fri gengivelse. Men derfor kan indholdet jo meget vel være rigtigt, hendes udvikling fra tysk påvirkning til klar dansk bekendelse og fra en urolig rationalisme til fredfyldt kristentro være ret opfattet og klart gengivet. Det er derom såvel som, og navnlig om hendes mand, nærværende afhandling vilde prøve at sige noget.

Samme forår, som jeg i februar havde fundet hendes navn 
og sted, tiltrådte jeg præsteembedet i Møgeltønder; var alts丸 ikke så langt fra Hollingsted, der nu ikke blot havde sin oldtidsinteresse som stedet, hvortil Bjovulfsdrapen har sagntilknytning (Hygelak, Hugleik, Holling), men også sin nutids-tiltrækning som stedet for hendes liv og strid. Jeg besøgte da også snart byen og fandt hendes grav, dækket af en flad sten med utydelig skrift; og rejste tilbage med tanken om at rejse sten på den med den indskrift. Høyer Møller slutter sin fortælling med at onske.

Men så måtte jeg jo i forbindelse med familien. Det skete gennem Peter Lassen, Strukstrup, som ved et made i Skærbæk kom til at fortælle, at hans daværende sognepræst hed Augustiny. Vi kom straks i venlig brevveksling.

Pastor Augustiny var søn af Hollingsted-præsten i 2. ægteskab. Han kendte godt Høyer Møllers fortælling, men mente ikke, skildringen af hendes udvikling var rigtig, men havde jo ganske vist ikke kendt hende; og han var - meget naturligt - utilfreds med de få og ikke særlig tiltalende streger, hvormed hans fader var tegnet. En ældre halvbroder til ham, altså hendes søn, nu pensioneret gymnasielærer i Gera (Reuss), var ret fortørnet over fortællingen, kunde præsten fortælle mig. Det gjorde mig jo ondt, men måtte vel i betragtning også af den nationale forskel ikke undre. Jeg indrømmede selvsagt ogsả straks, at deres fader burde være tegnet med mere sympati, uden at jeg dengang vidste noget nærmere om ham. Des villigere nu, da jeg har fået hans levned fyldigt oplyst. Hvad moderen angår, må jeg tro, at den skildrede dobbeltbevægelse, national og kristelig, er rigtig, om end den kan være understreget, stærkere markeret, end virkeligheden kunde svare til; det er jo netop al digtnings kendemærke. $O g$ da denne hendes udvikling foregik og var afklaret, mens hendes egne børn kun var små, og min korrespondent jo end ikke var født, måtte jeg mene, at Høyer Møllers kendskab til og forståelse af denne, en skøn sjæls bekendelser var dybere, end deres kunde være. Om et var der selvsagt 
fuld enighed, at hun havde været af de såre sjældne og fortjente den skønne skildring og varme tak, han giver udtryk i sin lille tale ved graven.

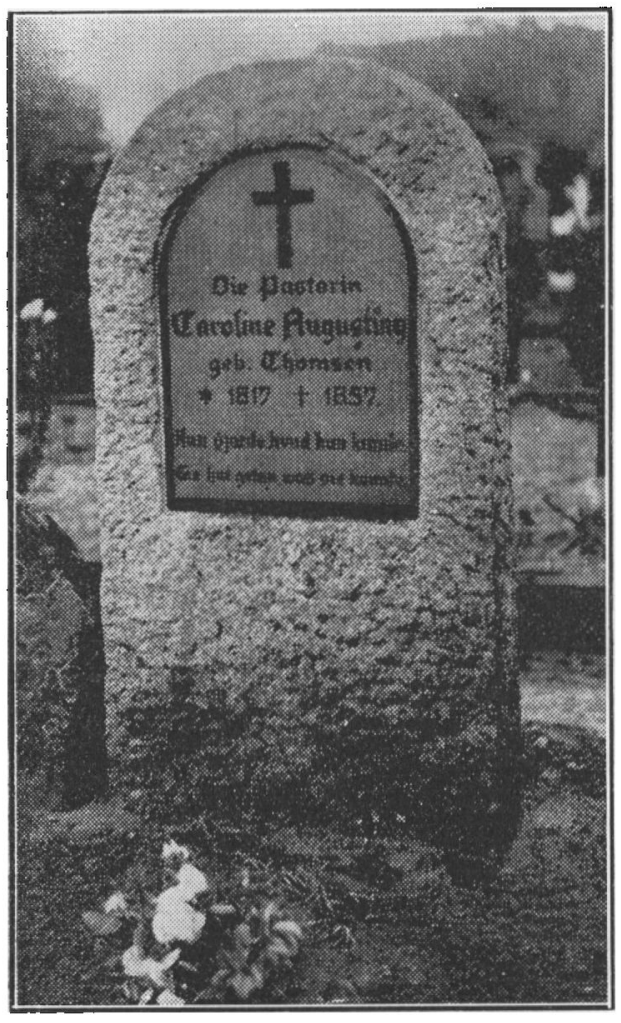

Familien havde følgelig intet imod, at jeg rejste en sten på hendes grav, men kunde dog ikke selv deltage deri. Pengene samlede jeg så, dels ved foredrag om hende, dels hos den gamle feltpræsts familie og venner. En stenhugger i Husum besørgede stenen med den af Høyer Møller ønskede dobbelte indskrift. Den 22 . april 1933 kørte vi, to familier fra Møgeltønder og pastor Holdt, Brede, derned. Det var altså hendes 76. jordfæestelsesdag. Jeg havde lånt $H$. M.s lille tale igen og læste den højt ved graven. Alt så stilfærdigt. Ingen andre tilstede. Men mindet holdt sin stærke, tysk tale og gjorde timen til en højtidsstund for os.

Danevirkes lave, vestlige afslutning ligger et par $\mathrm{km}$ ost for byen. Der spiste vi så vor medbragte frokost, mens lærkerne kvidrede over os i det smukke forårsvejr. Dronning Thyras værk i gamle dage og den trofaste præstekones stille kærlighedsvirke i nye tider smæltede sammen $i$ vort sind og vakte både takfyldte tanker og vemodige minder om det ved egne forsømmelser og misgreb tabte land. Minder, som binder. - -

- - Augustiny-sønnernes let forståelige uvilje mod Høyer Mallers streifbillede af deres fader satte en lille brod i min sam- 
vittighed. Ti ved at finde og fremdrage hans hustrus og dermed også hans navn blev jeg jo skyld $i$, at alle fremtidige læesere af "Tre af mine venner" kunde smile ad navnkendt mand. Høyer Møller er sagesløs, han har fortiet navnene; jeg er den eneste skyldige.

Det har derfor været mig kært at få lejlighed til, rigtignok først nu flere år efter, at studere hele Augustiny-slægten nøjere og tegne et andet og fyldigere billede af præsten i Hollingsted. Er det, som H. M. lærte præstekonen, umuligt at gøre godt igen, hvad man gjorde ilde, så kan man jo ialt fald - ifølge ordet, der gav navn til fortællingen om hende, - gøre, hvad man kan. Og gøres det som en samvittighedspligt og hjærtesag, tør man vel tro, det heller ikke er gjort forgæves.

Skildringen $i$ det følgende, der da midtsamler sig om præsten, er bygget væsentlig på skrifter af ham selv og hans søn, gymnasielæreren i Gera.

\section{Præsten Johan Rhode Friedrich Augustiny.}

Han tilhører en stærk, sønderjydsk slægt. Gennem 400 år har den bl. a. fostret mange præster. Og de blev ofte gamle. En sad i 61 àr i samme embede ( +1621 ), dog hjulpet tilsidst af en søn, der blev hans efterfølger. En anden kaldtes med rette »den stærke Friedrich“; nær de 3 snese bar han en dag en 500 pd.s ambolt ud af en smedie! I hans annex Fahrensted stod en del af Istedslaget (Stolk). Han døde 1852.

Dette og meget mere finder vi bl. a. i tidsskriftet "Die Heimat « for 1927 og 1930. Men vi vil her væsentlig nøjes med at følge en enkelt linje i slægten.

1. B e r tra m Augustini, født i Tønder, teol. student i København, vælges 1704 til kantor og rektor i Åbenrå. Formanden viste sig ofte beruset $i$ skolen, ja påskedag 1703 endog så fuld i kirken, at provst Ahrenkiel end ikke ved sin vinken fra altret kunde dæmpe hans råbende sang. Så måtte han afsættes. Derefter valgtes Bertram A. Han passede bægge embeder omhygge- 
ligt, blev en både anset og velstående mand, der kunde bygge sit eget hus på kirkepladsen. Her var siden dansk realskole $(1854-57)$ og præstegård. I 1890erne aflastes den af den nuværende tyske præstegård.

2. B a r th o ld Augustini, hans søn, blev hans, ligeledes dygtige, efterfølger $i$ bægge embeder. Tilsammen virkede de $i$ 85 år og søgte at faa det bedst mulige ud af datidens latinskole, hvor latin og religion efter Melanchtons anordning var omtrent de eneste fag. ${ }^{1}$ ) (I forbigående nævner vi en af Bartholds mange sønner: Thomas. Efter en fin eksamen i København blev han præst og nåede de 81 år, før han døde i Brodersby ved Slien juleaften 1823. Frederik 6 . hædrede den flittige præst med konsistorialrådstitlen. Han er fader til ovennævnte "stærke« Friedrich i Ølsby-Fahrensted).

3. Friedri ch Augustini, anden søn af Barthold, fortsætter linjen. Efter nogle år i latinskole, hvor han i alt fald lærer så meget, at han siden kan skrive latinske breve til sin far, kom han i købmandslære i Flensborg. År 1800 overtog han forpagtningen af den kgl. færgekro i Mysunde. Medens byen af det navn ligger syd for Slien og hører til Kosel sogn, ligger kroen på den nordlige side og hører til Brodersby. Han kom således til at bo i sin broder Thomas' sogn. Her blev han da også året efter viet til Anna Krabbe, provstedatter fra Sønderborg. Senere er han købmand forskellige steder i Gottorp amt; dør da også dær 1839 i sit virkested: Bøglund, der ligger i den stærke brodersøns pastorat og er naboby til Schleppegrells Øvre Stolk. Hans enke oplevede 3årskrigen hos sin søn i Hollingsted og døde dær 9. decbr. 1850. Vi noterer os dette, fordi det bidrager til indblik $i$, hvad svigerdatteren har haft at bære omsorg for.

Det er nu denne søn og svigerdatter, der skulde være hovedpersonerne i nærværende afhandling.

4. J o h a n R h ode Friedrich A. (navnet skrives fra nu

1) Jvfr. den slesv. holst. kirkeordinans af 1542 , (lig den danske af 1539): In allen steden und flecken schal eine schole syn [sein], darin man latin lere, unde geschickede scholmeisters hebben, der ein zuweliker [somme tider] twe edder dre tho hülpe hebbe. 
af med y) er født 6. april 1803 i Mysunde og døbt i Brodersby af farbror Thomas. Student fra Slesvig domskole 1821. Huslærer. Kandidat fra Gottorp 1828. Derefter huslærer i 9 år hos godsejer Henningsen på Schønhagen i Svans (Karby).

Allerede ved hans afgang fra latinskolen fár vi et lille indblik $i$, hvad der rørte sig i den unge mand. Han havde en kær ven i skolekammeraten Hinrich Nissen. I dennes stambog skrev han ved deres fælles bortrejse nogle hjærtelige ord, og dertil ude i randen: Rugbrød og frihed! Lidet tænkte de to venner, at den enes (A.s) datter skulde blive gift med den andens søn, og denne som præst i Arnæs, ganske vist 8 år før dette bryllup, holde ligtalen over sin tilkommende svigerfar. En søn af ham igen, stabslæge Karl Nissen i Berlin, er hovedkilde til det hidtil om Augustini-slægten anførte (se Die Heimat 1930).

Augustiny optræder tidligt som forfatter. Allerede i Schønhagen syssler han med "kirkeåret« og fảr "Die heiligen Zeiten der christlichen Kirche trykt i Slesvig 1838. Det er en række kristelige digte med et kort tillæg om tilblivelsen og betydningen af søn- og helligdagene, helligdagenes 1 a tinske navne; bestemt til husandagt.

Samme år kaldes han til præst, degn og lærer på Oland, en af de små Halliger, og får nu god brug for, hvad han har sanket sig af viden og øvelse i de mange ungdomsár. Men den lille var et såre ensomt sted. Godt da, at han allerede 28. februar 1838 kunde holde bryllup med den unge pige, som de mange år efter gennem Høyer Møllers skildring skulde få så stor en plads i mange danskes, især kristne danskes hjærter.

Caroline Catarina Christine Thomsen var fodt 18. februar 1817 som datter af godsejer Jensenius Thomsen og Henriette v. Barner på gården Brunsholm i Eskris, sydøstlig i Flensborg amt. Hendes far var fra gården Dyttebøl i Gelting; hendes mor dansk majordatter fra København. Faderen dør i datterens føidselsår, og moderen gifter sig 2. gang med løjtnant v. John-Marteville på Snarup i Tumby sogn, så Caroline Thomsens unge år tilhører helt Angel, hvor den jævne befolkning 
endnu kunde dansk, medens de højere klasser næppe har villet bruge det. Skønt hendes mor naturligvis har kunnet dansk, og hendes stedfar vel har været loyal officer, $i$ alt fald $i$ hendes opvækst, så hun fik og bevarede dansk sindelag ligesom sin mand, lærte hun alligevel ikke at tale dansk. Men det er jo kun, hvad er så velkendt: at man både den gang og senere kunde være tysk af sprog og dog dansk, loyal dansk af sind. Hendes mand synes - efter hans bøger at dømme - at have kunnet det bedre. Studierne kan have ført det med sig. Hun har haft så lidt lejlighed til, at høre det, idet moderen ikke synes at have talt det med sine børn. I følge Høyer Møllers fremstilling har hun dog kendt så meget til det, at hun holdt af dets bløde melodi, mer det kan jo høre til fortællingens "Dichtung«, ligesom når han for at øge den tragiske spænding $i$ hendes levned lader hende blive gift som 18 årig og føde 4 sønner på Oland uden jordemoder-hjælp, skønt "Wahrheit" er, at hun var 21, da hun blev gift, og fødte sin førstefødte, inden hun kom over til den lille fjærne skulde vel lunes, før han hentede hende.

- - - Halliger kaldes de småøer, der ligger som trinbrætter mellem Føhr og Amrum i nordvest, Pelworm og Nordstrand i syd. Der er 16, men kun 8 er beboede, og kun 4 har kirker: Oland, Langenæs, Hooge og Gröde. Havet slider dem stadig mindre. På opkastede værfter må husene bygges, og så kan stormfloden endda sætte ind, så man må søge tilflugt på lofter og tage.

0 l and havde før stormfloden i 1825 et 2 timers omfang. I 1838, da Augustiny kom derover, kunde man gå den rundt på 1 time. Den var på 35 ha. Tidligere lå på dens 3 værfter: 40 huse på det ene; 20 på det andet; præstegård, kirke og skole på det tredje. $\mathrm{Nu}$ var der kun $21,2,2$ (skolen borte), og i de 23 huse boede der 76 mennesker. Så kunde en stue i præstegården jo nok slå til som skolestue. Senere er tallet endda sunket til 13 huse med 43 sjæle.

Mændene lever på søen, farer helt til Grenland. Kvinderne bjærger hø fra de frodige enge, $25-30$ pd. kan de bære på deres ranke hoveder; passer de få køer, klipper fårene og spinder, spin- 
der næsten året rundt, alt til deres behov. Og så har beboerne én indtægtskilde til: strandingsgods. Man nøjedes endda ikke med at sanke og dele det, med præsten som selvfølgelig lodtager, men det hørte med i søndagens kirkebøn fra prædikestolen at bede om stranding(!). Denne stygge uskik afskaffede Augustiny, straks han kom derover. $O g$ han synes ikke at have mødt indsigelse derimod. Han var i dette som $i$ andet udtryk for "den stille magt«, der går sin gang gennem tiden og vinder sine stille sejre.

Præstefolkene faldt $i$ det hele udmærket til i denne lille fjærne verden. Præsten var ikke blot præst og degn og lærer, men endog apoteker, for så vidt altså også læge. Lidt landbrug havde de da også som de andre "bønder; og dertil deres fåreflok. Ugens eller dagens afbrydelse i ensformigheden, for så vidt man kan tale om ensformighed, hvor man er omgivet af det altid skiftende hav med storm og stille, sol og sky, var budet, der kom ovre fra fastlandets store verden, Jens Post, med en smule avis og breve fra de søfarende mænd. Jens Løber kaldtes han ellers og havde som sin særlige passion at tygge tobakskrads, så mundvigene mørknedes derved. Det faldt ikke i præstekonens smag eller sans for renlighed; men værre blev det, da hun opdagede, at pigen Marie nærede samme tilbøjelighed! Til modsat side måtte det blive hende en glædelig overraskelse, at øens yngre kvinder ikke var ukendt med læsning; hun fandt både Goethe og Schiller på deres små hylder til tidkort i de lange aftener, medens drengene nærede deres fantasi med Hoffmanns æeventyr som forberedelse til selv at komme ud og opleve de lange rejsers spænding.

En lykkelig tid kalder fru Augustiny de 6 år her; ti vel var de både afsondrede og fattige og altid udsat for stormflodens fare, men her var fred $i$ det lille samfund, navnlig fred for den politiske strid, der siden skulde gore dem livet i Hollingsted tungere.

Og her kunde også opleves festlige dage. Kong Kristian 8. gjorde sine årlige baderejser til det nære Føhr; og så hændte det, han også gæstede Oland. 
Ved et sådant besøg skrev præsten en sang til landsfaderens ære, fulgte ham rundt til de gamle og syge, hørte med glæde. hvordan kongen talte plattysk med dem, og modtog senere gaver fra ham til uddeling iblandt dem.

Et år var dronning Karoline Amalie med, og flere fornemme personer, bl. a. prinsen af Noer. Også H. C. Andersen var efter majestæternes venlige indbydelse kommen derover. I »Mit Livs Eventyr" giver han en malende skildring af "disse Græsruner i Havet, der melde om et sjunket Land «:

"Oland, som vi besøgte, har en lille By; Husene staae tæt op til hinanden, som ville ogsaa disse i Nøden slutte sig sammen; de ere alle rejste på et Bjelkelag og have smaa Vinduer som Skibskahytter; her i den panelede, lille Stue sidder halvaarsvis eensomt ved deres Spinderok Koner og Døttre; her er altid en lille Bogsamling, jeg fandt danske, tydske og frisiske Bøger.... I Stormfloden 1825 bortskylledes Huse og Mennesker, halvnøgne sad de i Nætter og Dage paa Tagene, til disse sank; ingen fra Føhr eller Fastlandet kunde bringe Hjælp; Kirkegaarden er halv bortskyllet, Kister og Liig stikke nu i Brændingen, det er et rystende Syn....

Med de kongelige Herskaber besøgte jeg Øen .... Iil ikke, see Dem ret omkring, sagde Kongen venligt, lad Baaden kun vente! see den gamle Kirkegaard og gaae ind i Huset der og see en smuk, ung Kone! .... Foran Kirken havde de rejst en Fresport af Blomster, hentede fra Føhr.... Øens eneste Træ, en Rosenhæk, havde de skaaret af for at lægge den over et sumpet Sted, hvor Dronningen skulde gaae; det rørte den gode Dronning dybt. - Smukke ere Pigerne og halv orientalsk klædte; de regne sig ogsaa i Slægtlinie fra Grækerne. Ansigterne ere næsten halvt tilhyllede, og under Linet bære de en rød, græsk Fesz, om hvilken Haaret er lagt i Fletning.

Vor Sejlads tilbage gik mellem et Archipelagus af Øer; ved den dejlige Solnedgang blev Skibsdækket ihast indrettet til Dandsesal. Gamle og Unge dandsede; Lakajer bød Forfriskninger, Matroser loddede Vandet og raabte Dybderne. Maanen gik 
op, saa rund og stor, Sandklitterne paa Amrom syntes at løfte sig son en sneebedækt Alperække.« -

Men der kom også besøg af anden art, farlig art. Fru Augustiny nævner i sin førnævnte skildring til Høyer Møller to. Hun giver en gribende skildring af en stormflod: Havet stiger, vandet oversvømmer alt, umuligt at komme fra det ene hus til det andet, solen synker blodrød, høje, hvide skumkamme styrter ind mod vort hjem, alt blir mørkt. Min mand stængede døren, satte skodderne for vinduerne, vi var i nød og vidste, der var 5 timer, til vandet kunde falde. Vi tændte lys, talte kun lidt, ti næsten umuligt a.t raabe hinanden op. Vandet steg, buldrede mod døren, trådte ind til os, løftede en pind fra gulvet, ja en træskammel.... Vi satte vuggen op på loftet, jeg satte mig ved siden af, min mand stod på trappen og lyttede mod stormsiden.... - Men hun kan også så herligt føje til: Jeg kendte dog ikke til frygt; jeg befalede mig og mine i Herrens hånd, og der var den hele nat en fred i mit hjærte, som Han gav, der kan sige til stormen: Ti og vær stille!

Dette er jo nu igen Høyer Møllers gengivelse. Men den stemmer godt nok med en fra hendes egen ældste søn, som i sine livserindringer atter og atter røber en ualmindelig sikker hukommelse. Det er fra en anden stormflod, i begyndelsen af 44. Han er da godt 5 år og mindes, hvorledes hans far lagde sandsække foran yderdøren, hvorefter forældrene satte sig stille hen med børnene klyngende sig til dem og ventede således på den gryende dag, der viste dem et frygteligt syn af strandingsgods rundt om.

Samme søn, hvis udmærkede bog "Feuerabenderzählungen eines Siebzigjährigen" har været kilde til en del af det foregaaende og vil blive det delvis til det følgende, fortæller også om det andet farlige besøg: Boghandler Brockhaus fra Leipzig kommer, som badegæst på Føhr, over til Oland på besøg, ser præstefolkenes små kår, navnlig så få bøger, og sender dem efter sin hjemkomst en stor kasse fuld som ren gave, bảde skønlitteratur og teologiske bøger. Men hos Høyer Møller føjer fruen rigtignok til, 
at der også var en slange $i$ det bogparadis: slesvig-holstenske pjecer, der kastede uro i deres sind, især da de i aug. 44 kom over til deres ny menighed og så disse tanker i kød og blod. -

Med et smukt besøg på Føhr for at takke Kristian 8. for forflyttelsen og med en vemodig-glad afsked fra den lille, taknemlige menighed sluttede de deres gærning på Oland og drog til Hollingsted.

Endnu skal kun tilføjes, at pastor Augustiny også markerede dette afsnit af sit liv med en lille bog: Vier Predigten (Jul, nytår, 4. s. e. h3k., 17. s. e. trin.) Husum 1842. Vi mærker os, at texten til 4. s. e. h3k. er "Jesus stiller stormen på søen«. 17. s. e. trin. handler om selvophøjelse og ydmyghed. -

Hollingsted ligger, hvor det torre højland i ost går over til det våde lavland i vest, så Danevirke-volden ikke behøvede at fortsættes længere, i alt fald ikke i hine fjærne tider, da det våde var mere vådt end siden hen.

Præstegården, hvortil familien nu flyttede, havde historie. Så fornemme personer som tsar Peter og kong Frederik 4. har boet der en tid i februar 1713. Og i decbr. 1813 tog Russergeneralen v. Tettenborn kvarter i præstegården tillige med en kosakritmester v. Bismarck og den kendte digter Varnhagen von Ense som Tettenborns adjudant.

$\mathrm{Nu}$ var det et par fattige og fredelskende præstefolk, der flyttede ind med deres 4 smådrenge, der her kunde få en nok så stor tumleplads som på den lille ø. Bl. a. drev præsten i de første år selv avlingen og havde således både heste og køer, der jo gærne er raske drenges glæde.

Sognets folk var rent plattysk talende uden dansk accent eller indblanding. Præstens fik også inden længe at mærke, at de tillige var slesvig-holstensk sindede. Husene var i den nedersachsiske stil, for halvdelens vedkommende endnu uden skorsten ( 32 af 67 ). I den af 3 gader bestående lille by brugte man natvægter. Han gik sin runde Kl. 10, 12 og 2 og måtte ved enden af gaderne banke på visse ruder for at godtgøre, at han havde gået $\sin$ tur. Befolkningen var naturligvis fuldkommen 
fremmed for alt det, der i hine år vågnede og rørte sig så kraftigt i Nordslesvig. Men var de udenfor den med opvågnen og kamp altid følgende uro, skulde de alligevel få mer end nok af forvirring; ti den, der ikke vil det rette, nødes ind i det urette. Ikke blot al fortumlingen af de slesvigholstenske tanker kom over dem, men også skuffelserne med de skiftende tilhørsforhold, som fulgte deraf. Det afspejler sig f. ex. i deres mont. I lobet af 19 år (1854-73) havde de 4 mønsystemer: dansk til 64, slesvig-holstensk til 67, prøjsisk til 73, derefter alm. tysk. Det er farligt for så lille en landsdel at ville være noget for sig; man ruller let frem og tilbage som stenen i strandkanten, blot med den forskel, at stenen bliver rund, mennesket kantet. Og hernede mere end i Nordslesvig vilde man netop være noget for sig. Lærde folk havde givet det udtryk $i$ et latinsk distichon (vers): Slesvicum et Jutland dirimit Scotburgicus amnis.

Eydora Teutonicum terminat imperium.

(Skodborg å skiller Slesvig fra Jylland, Ejder er grænse mod Tyskland).

Hvordan så skoleforhold ud dernede? Selvfølgelig var sproget udelukkende tysk både i kirke og skole, som det måtte være. Ogi ellers var selve udviklingstrinnet noget ud over almindelige landsbyforhold, da Hollingsted var så stor, som den var. I fordums tid havde man været nøjsom nok! Også med hvad man kunde bruge som degne. I 1683 havde bønderne f. ex. valgt en håndværkssvend, fordi han havde sunget så smukt henne i værtshuset! I det 19. årh. var man nået til at have både en god degn og en seminarieuddannet lærer ved byens skole, og de kunde undervise ikke blot i de almindelige færdigheder, men i geografi (alle Danmarks byer!), historie, zoologi, ja endog lidt astronomi. Men til biskolerne om vinteren ude $\mathbf{i}$ sognets mindre byer kunde man endnu bruge halvvoksne knøse, der havde været hyrder om sommeren. Skoler havde man ikke til dem, man hjalp sig med at låne pidselen (storstuen) $i$ en bondegård.

Og nu præstefolkene i deres ny gærning? De gik efter alt 
at dømme op i den med samme flid og samvittighedsfuldhed som på Oland, levede sig hurtigt sammen med befolkningen (trods forskelligt politisk syn), hvad to betydelige bøger, vi senere skal omtale, bærer vidne om, idet præsten her netop skildrer sognets historie og egnens sprog med kærlighedens forståelse. Versuch einer Chronik des Kirchspiels Hollingstedt (1852), hedder den ene, mens den anden bærer den plattyske titel: Achtern Åben oder Platdütsches Vålksbok för Kinner un ole Lüd (1857). (Achtern Áben 5: bag ovnen, ved arnen). Ligesom han paa Oland havde afskaffet en uskik, således også her en. Folk, der af en eller anden lyssky årsag ikke ønskede at vies af deres hjemegns præst, plejede for gode ord og betaling at kunne få en anden til det; det skete så endog stundom om natten. Augustiny sagde bestemt og strax nej til dette.

At han har haft et virkeligt evangelisk bud at bringe, bærer hans skrifter vidnesbyrd om. En af de vanskelige opgaver $i$ en præsts gærning - ligtaler - løste han ved at give dem afgjort bibelsk indhold og derved undgå at dvæle for meget ved det personlige.

Fra krigens tid er opbevaret, i sønnens bog, en interessant oplevelse. Efter Istedsejren blev egnen besat af soldater, og dette i Hollingsted sogn sådan, at danske forposter besætter hovedbyen, tyske de små sydlige byer. En dag onsker en syg i det sydlige at modtage nadveren. Den danske oberst Bentzen, indkvarteret i præstegården, ledsager beredvilligt præsten, begge til hest, et stykke af vejen. Men da nogle opkastede skanser skal passeres, må præsten have bind for øjnene, og en soldat føre hans hest. Ligeså på tilbagevejen. Alt forløber tilfredsstillende.

Men nu det ulmende og siden brændende nationale spørgsmål? Bægge præstens forældre var jo opvoxede i Nordslesvig (Abenrå og Sønderborg), har følgelig kunnet tale sønderjysk, men har måske ikke brugt det nede ved slien. At sønnen dog har hørt en del Angel-dansk i sin opvæxt dernede og lært det med barnets hurtighed, er der ingen tvivl om; en af hans bøger 
viser det. Derimod har han næppe haft lejlighed til at tale rigsdansk, men har tilegnet sig både det og svensk ad læsningens $V$ iej (han har f. ex. oversat digte fra svensk til plattysk), men synes ikke at være bleven helt sikker $i$ at tale det, om end meget bedre, end vi af Høyer Møllers strejfbemærkninger får indtryk af. Viljen var der i alt fald, hvad en udtalelse af ham godt nok røber. Det er Holger Hjelholt, der i sin doktordisputats om den danske sprogordning har opbevaret den (s. 211). Augustiny, på det tidspunkt vicar i Treja, skriver: "Er først hjemgangen det nuværende Slægt, så vil det nok blive bedre i denne Hensigt, at de frafaldne og bortgangne Born ville vende tilbage til deres gamle Moder og føle med en sød Vemodighed, hvad Modersmaalet er for en deilig Lyd".

Har han virkelig tænkt sig disse sydlige egne blive dansktalende og øjensynlig onsket det, er dermed jo også givet, at hans sindelag var dansk. At han og hans hustru så har haft svage øjeblikke $\mathrm{i}$ oprørets forvirring, sådan som Høyer Møller så grilsende lader fruen skildre det, er sikkert nok. ${ }^{2}$ ) Givet er dog, at deres hu vendte mod nord, selv om deres sprog var tysk; de to ting følges som bekendt ikke altid ad hernede. Der er vidnesbyrd nok, særlig $i$ en af hans bøger, om dette sindelag.

Der var et ejendommeligt forhold, hvor han kom til at vise sympati for både tysk og dansk mod engelsk eller vel rettere sagt antipati mod noget, der med rette syntes ham upraktisk. En Englænder, Sir Morten Peto havde fảet consession på anlæg af jærnbaner i Sønderjylland. Så vakte det præstens og naturligvis mange andre praktiske menneskers undrende uvilje, at han lod dem gå udenom Frederiksstad og Slesvig, fordi de var tyske, og udenom Ábenrå og Haderslev, fordi det var billigere at fore dem op ad det jævne højdedrag vest for dem. (Den-

2) Den provis. regerings ændring i maj 1848 af kirkebønnen fra "konge" til det uklare "fyrste" gik han med til. Ligeledes underskrev han erklæringerne af 2 ?. aug. 1849 og 15 . oktbr. s. a. mod den kgl. regeringskommission (Tillisch $\mathrm{m}$. fl.) Se provst $\mathrm{N}$. Nielsen: Materialen.... S. 38 og 42 . 
ne nord-linje påbegyndtes først i 1862). Og end mere, at billetterne lige til 64 blev ved at have engelsk tryk, ligesom personalet brugte engelske færdselsudtryk: Stop! Go on!

At præstens straks ved krigens udbrud fra dansk side blev slået i hartkorn med de mange afgjort oprørske embedsmænd, kan ikke undre. Sikre, men lavmælede standpunkter overhøres i krigslarm. Således kom der to dage efter slaget ved Bov to danske dragoner til præstegården, ledende efter nogle oprørssoldater. Præsten som den eneste, der forstod dansk, fik et par pistoler for brystet, uden at der dog kom noget synderligt ud af brystet af den grund. Derimod bragte fruen mælk og brød til de sultne krigskarle, hvis menneskekundskab dog ikke var større, end at de kunde tiltænke dette ansigt og denne hånd at blande gift i maden, hvorfor hun til deres beroligelse spiste lidt af maden først!

Påskedagsslaget 14 dage efter kunde naturligvis høres og gjorde stærkt indtryk. Ligeså Egernførde-affæren 5. april året efter. Det var jo skærtorsdag, og tordenen hørtes stærkt allerede før kirketid. En urolig morgen: Pigen græder, for hun har nok en ven med på den ene side; fruen trøster hende, skønt hun har sit hjærte på den anden side; præsten er optaget af den storre skærtorsdagskamp, han skal tale om i kirken; og den ældste søn, nu 11 år, hælder noget til samme side som pigen og det store sogneflertal, hvis ungdom i stort tal var med; i alt fald taler han i sine livserindringer om kampen mellem "danskerne og v o r e«. Men det er måske et ubevidst farvet erindringsbillede, ti andensteds kalder han det en ulykke, at en sl. holst. kugle skad det tov over, hvormed Gefion skulde været slæbt ud af kampen.

Efter sejren ved Isted året efter kunde den danske hær spredes langs Danevirke og helt vest ud. Der kom da fast indkvartering for lang tid $\mathrm{i}$ de urolige sogne. Til Hollingsted kom der sidst $i$ august $1 / 2$ batteri og en deling Alborg-dragoner. Fra den tid er det da, Høyer Møllers gærning begynder; $i$ år og dag fær- 
dedes han uafbrudt fra øst til vest og holdt tjenester i hele 14 sydslesvigske kirker.

Et træk fra den tid viser os, hvorledes pastor Augustiny kunde sætte det personlige højere end det politiske, og hvilken tillid han nød også blandt modstandere. En højere embedsmand i Slesvig, udpræget Slesvigholstener, Kirchner hed han, blev strax efter Isted eftersporet fra dansk side og flygtede derfor bort i forklædning. Nær kending af præsten, som han var fra tidligere tider, ilede han til Hollingsted og bad om hjælp til videre flugt. "Jeg ved, vi ser modsat på tingene, men vover alligevel at bede Dem om hjælp«. Fruen bad den forkomne mand spise til middag med dem, syede derefter et par guldstykker ind $i$ hans vest, hvorefter præsten fulgte ham et stykke på vej og gav ham besked om videre vej sydpå. - En ung pige fra Slesvig, også tysksindet, var i præstegården for at lære husholdning hos den dygtige husmoder; hun kendte og genkendte flygtningen og kom til at holde end mere af præstefolkene, uden i mindste måde at få sin tro på deres danske sindelag svækket. Mange år efter erfarede præsten, hvor meget dette havde betydet rent personligt for hr. Kirchner.

Under og efter Frederiksstads forsvar lærte præstens den tapre oberst Helgesen at kende. Det blev i årenes løb til et nært kendskab, ikke mindst $i$ det års tid $56-57$, da Helgesen boede $i$ Hollingsted. Han kom da jævnlig i præstegården, og sønnerne dær gik ofte bud til ham og så med undren de tamme fiskeoddere i hans bolig. Da han døde i 58, deltog pastor Augustiny i begravelsen.

Da disse præstedrenge blev større og ikke kunde, nøjes med byskolens undervisning, fik de huslærere og altid danske. En ritmester fra Næstved blev efter krigen forsat til Slesvig. Han havde 2 sønner på alder med præstens tvillinger. Da de to tyskukyndige drenge ikke ret kunde følge med i domskolens undervisning, der helt gik på tysk (mens den i Flensborg blev omtr. halvt af hver, og den i Haderslev blev indrettet helt dansk), 
kom de ud til Hollingsted præstegård, medens omvendt den ældste derude nu kom ind i domskolen, af hvis 8 lærere de 4 nu var nord fra: Manicus, Blichert, Listow og Vilh. Johannsen, men altså måtte undervise på tysk.

Samme søns udviklingslinje er forøvrigt lærerig. Havde han haft en smule drenget lyst til at wholde med" cprorerne, sad det ikke dybere $i$ ham, end at han delte forældrenes kærlighed til oberst Bentzen, der havde været så længe indkvarteret hos dem og fra $54-64$ havde garnison i Slesvig, ligesom han ogsaa kun kom i danske familier i Flensborg, hvorhen han siden flyttedes. Især glædede han sig ved at komme hos den stilfærdige, milde danske biskop Boesen. Men liden tue kan om ikke vælte et læs, så dog få det til at skride. Således her. En dag var han hos en familie, hvor en af døtrene just fik syet en ny kjole af en kun tysktalende syerske. Under den danske samtale $i$ dagligstuen råber datteren en besked på tysk ind til sypigen, hvorpaa fruen i vrede udbryder: Du ved da nok, at her i stuen taler vi ikke tysk, og ledsagede bemærkningen med en kraftig lussing. Det forargede ham. Da han var bleven student, modsatte han sig faderens ønske om at studere i København, gik til Kiel og blev så forøvrigt siden teol. kand. og dr. phil. og endte som en anset lærer ved gymnasiet i Gera, hvor han efter sin afgang i 1907 skrev sine Feuerabenderzählungen, ligesom han tidligere havde brugt sin pen tíl adskilligt. Han døde 87 år gl. i 1925. Han er vel drengen, der i Hayer M.'s fortælling blir årsag til Zakkæos-samtalen.

Et enkelt træk skal lige anføres fra hans tid i Slesvig domskole; atter betegnende for, hvad der gør indtryk på ungdom. Man havde hørt, at der $i$ anledning af Krimkrigen lå en engelskfransk flåde i Kiel, og bad derfor om for de større disciple at fả et par fridage til at se den. Tilladelsen blev givet, og den lange marchtur gennemførtes med højt humør trods øsende regn. De mægtige krigsskibe gjorde et overvældende indtryk på dem, og i tilsvarende grad fik et ensomt lille dansk krigsskib dem til at 
tænke ringe om Danmark. Drenge tror lettere, at magt er ånd, end at and er magt.

Men at denne fru Augustinys førstefødte dog bevarede sansen for åndens verden, turde fremgå af de ord, hvormed han som 70 årig ser tilbage på sin livsgærning: "Vemod fylder min sjæl! En af de alvorligste, sværeste stunder i mit liv er nu kommen. Afskedsstunden. Det er den sidste. Så siger jeg da: Tak til Gud, til stedets fyrste [Reuss], til medlærere og elever. Gud den almægtige holde sin skærmende og velsignende hånd over min gamle skole, über alle die hier lehren; über alle die hier lernen! Amen!« -

Men tilbage til forældrene i Hollingsted. Svag havde fru Augustiny vist længe været. Det grødefulde forår med sin skarpe blæst ind imellem er altid farligst; det tog også hende. Den 17. april 1857 lukkede hun sine trætte øjne. - Hvad hendes mand talte ved hendes kiste, kendes ikke. Sonnen kalder hende den fødte præstekone, fuld af moderkærlig omhu for alle lidende. Hvad Hoyer Møller talte, og áringer efter skrev, ${ }^{3}$ ) er meddelt i Indledningen. -

Også sin moder havde pastor Augustiny måttet gemme på Hollingsted kirkegård. Hun havde jo som før nævnt været $i$ præstegården på sine ældste dage og døde den 9 . decbr. 1850, 77 år gl.

Godt et år efter ægter pastor Augustiny sin første hustrus halvsøster, Gønna v. John fra Snarup i Tumby sogn. Også dette ægteskab omtaler hans ældste søn som meget lykkeligt. Som i det første fødtes her 4 børn.

I 1862 forflyttes pastor Augustiny til sit sidste embede, Ulsnæs der hjemme i barndomsegnen nord for Slien.

Et ord, hvormed han slutter den fortræffelige lille "Chronik " om Hollingsted, kan passende slutte også dette afsnit. Vel er det skrevet allerede 1852, men kunde vel også gælde 1862. Han taler her således til sin menighed:

3) Bogen »Tre af mine venner" er fra 1879. 
Vi har nu levet 8 år med hinanden og er gået gennem krig og fred, og du har i alle dine medlemmer givet mig mangt et bevis på din kærlighed, venlighed og tillid. Vel var der i dig og må vel endnu være dem, der ser på de sidste års tildragelser med andre øjne end jeg, dog har denne meningsforskel ingen afbrydelse forvoldt $i$ vort forhold. Jeg bærer dig på mit hjærte og vil aldrig glemme dig, selv om en ydre adskillelse skulde finde sted. Engang skal jeg jo sammen med dig træde frem for Herrens domstol og af hans mund høre dette sporgsmål: Hvor og hvorledes har du græsset disse får og lam? På evangeliets stedsegrønne enge eller $\mathrm{i}$ den forgængelige verdens tørre orkner? Har du ført dem til det levende vands kilde eller til de sprukne brønde, som ikke giver vand? Hollingsted kan jeg ikke glemme, hverken de levende eller de døde. Også blandt dem har jeg en, som blev mig dyrebar fremfor alle, en moder, om hvem jeg kan sige, som Claudius sagde om sin moder: Som hun elskede mig, således elsker ingen mig mere på jord! Guds rige formere sig da i dig, kære menighed, og nå derhen, hvor det endnu ikke er kommen. Guds velsignelse blive hos dig og hvile over dine born efter dig! Guds fred bevare alle hjærter, som hører dig til, i Kristus Jesus vor Herre. Amen! -

Den præst, der kan skrive sådan, efter at en krig har bragt dybt skel ind mellem dem, han er så vist ingen hverdags-mand; tvertimod. - - -

- Og så skulde han få lejlighed til at vise sin åndelige kraft og sikre personlighed i dens stille styrke én gang til! Ti også i U l s næs kom en krig og skabte sin uro og satte sine skel. Og denne gang blev det ham, der stod på nederlagets side.

I septbr. 62 flytter de til Ulsnæs. Og allerede 8. novbr. bliver præsten bedt til middag med kong Frederik 7. hos herredsfoged Buchwald i Kappel. Kongen befandt sig jo altid så vel i Sønderjylland borte fra hovedstadens ceremoniel og - mảske - borte fra Ejderpolitikens mænd. Dagen efter vilde han sejle med den lille rutedamper til Slesvig. Adjudanten meddelte bekymret, at kahytsdorene var for smalle! Så er dækket vel da 
bredt nok! lo kongen. Men kun et år efter dørde det sidste smil på den folkekære konges kind, og ulykkerne brød ind over vort land.

Den 18. januar 64 får præstens oftnævnte ældste søn, på den tid lærer i Hamborg, ordré til at melde sig i Fredericia som militærarbejder! Faderen tilråder: Adlyder du ikke, kan vi måske heller aldrig ses mere her i hjemmet. Den gamle troede ikke på krig, allermindst på uheldigt udfald; den unge lige modsat. Betegnende for 2 slægtled. Dette faderens kaldende brev er det sidste, han kan sende frankeret med et dansk 4 skillingsmærke. Vandene skilles!

Den skæbnesvangre februar oprinder. Den 1. går Wrangel over

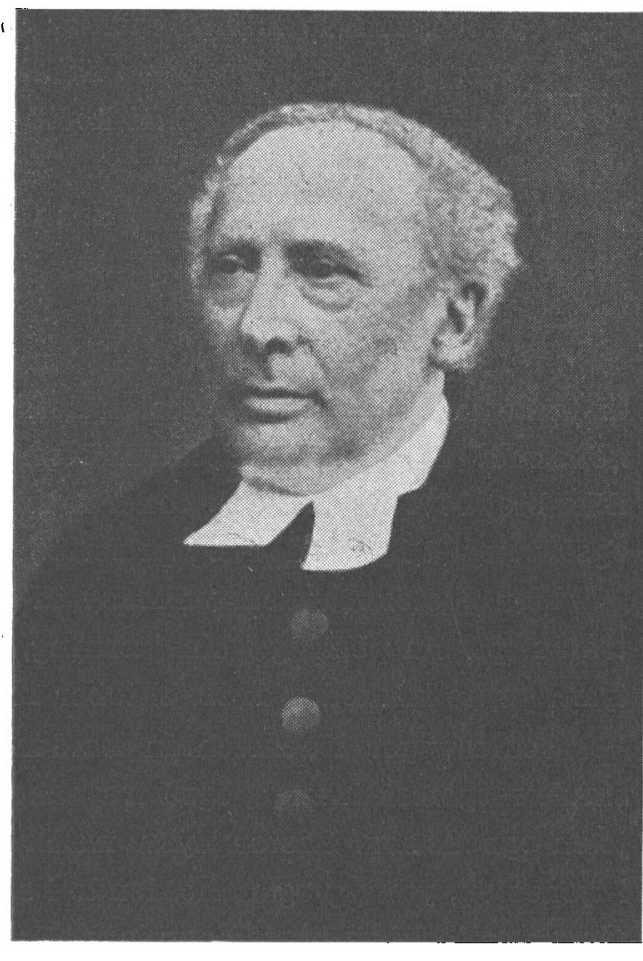

Pastor Augustiny, 1803-1880

(efter „Die Heimat" 1930)

Ejder. Den 2. forsøger Friedrich Carl at gå over Sli ved Mysunde; det mislykkes. Den 6. lykkes det ved Kappel og Arnæs. Mellem de to steder ligger Ulsnæs. Trange dage i præstehjemmet! Så meget mere, som sognets folk var sindede som i Hollingsted; ikke så lidt skarpere. Og hæren havde forladt Danevirke d. 5. Alt slog sammen! Et par dage efter hed det sig, at de dansksindede embedsmænd, også de i Sønderjylland fødte, skulde udjages. Rygtet når ned til sønnen, der af uro for sin far søger orlov fra sin skole, iler hjem og finder alt roligt. Hans far 
havde trods den korte tid allerede vundet sognets tillid og respekt. Til yderligere sikkerhed henvender sønnen sig til Hansen-Grumby, kendt slesvig-holstensk stænderdeputeret. Denne lover at sikre hans far mod afsættelse. Men $d .26$. i den samme begivenhedssvangre måned melder sønnen sig til hertug "Friedrich 8."s tjeneste! Vandene skilles endog i hjemmet! Han kom dog ikke til at kæmpe, ti hertugens armé nåede aldrig anerkendelse af det tyske forbund. Ingen blev vel dybere skuffet end han. "De kyllinger, vi selv har udklækket, kan vi ogsaa selv vride halsen om på ", som Bismarck sagde. Dat mött wi hebben - og derved blev det.

Skuffelsen voxede i 66 ved Østerrigs nederlag. D. 24. jan. 67 indlemmedes Slesvig-Holsten som provins i Prøjsen. $101 \mathrm{ka}-$ nonskud! Koral fra kirketårn: Nun danket alle Gott! Det var ikke blot i Nordslesvig, de toner fremkaldte sorg og tårer; de gik også tungt til et fader- og præstehjærte i Ulsnæs ved Slien.

Men pastor Augustiny fik lov til at blive; og han blev! Blev trofast på sin post og i sin gærning, til kræfterne svandt, og to trætte øjne lukkedes d. 12. oktober 1880. Han gik da i sit 78. ár.

Schleswiger Nachrichten kalder jordfæstelsen en sjælden smuk sørgefest. Mange, også fra nabosognene, var med. Han var jo en egnens søn. Pastor Eyler fra Brodersby kalder ham trofast i tjenesten, ydmyg og udholdende i sjælehyrdens gærning. Endvidere talte både pastor Paulsen, Gelting og pastor Nissen, Arnæs; den ene var en slægtning, den anden blev det, som før nævnt, senere som svigersøn. Yderligere var 5 præster deltagende $i$ afskedsfesten, der længe mindedes som båret af ærlig sorg og hjærtelig tak.

Flensb. Avis giver den afdøde flg. smukke eftermæle: "Pastor Augustiny i Ulsnæs afgik i tirsdags ved døden i en alder af rigelig 77 år. Den afdøde var en ædel karakter, en nidkær sjælesørger og en trofast ven, hvorfor han også havde vundet mange hjærter for sig. (Så nævnes hans 3 embeder). Endskønt han i oprørsårene lod sig forlede til at gøre et ubesindigt skridt sammen med de fleste andre præster i Sydslesvig, så var han alli- 
gevel af hjærtet en dansk mand, der gærne vilde være sin konge og sin rette ovrighed lydig. Han var en ven af skolen og tog $i$ y ngre år levende del $\mathrm{i}$ alt, hvad der skete til fremme for skolen og lærerens stilling. Den beskedne og venlige præst måtte absolut vinde enhver retsindigs hjærte; $i$ hans trofaste, smukke øje spejlede sig hans ædle tænkemåde, og hans hjærtelige sprog drog de fleste med sig. Hans minde vil leve længe blandt alle dem, der har haft lejlighed til at træde i nærmere berørelse med ham. Medens han var sognepræst i Hollingsted, udgav han nogle historiske efterretninger om Hollingsted sogn".

Endelig finder vi i bladet Dannevirke for. 8. marts 1851 en udtalelse, som er desmere værdifuld, fordi den stammer fra tiden lige efter den krig, hvor pastor Augustiny havde haft sit svage øjeblik. Det er en dansk soldat, der i en længere artikel om Hollingsted skriver: "Velstand synes omtr. hvermands eje i denne by, hvis hæderlige præst Augustiny — såvelsom skolelæreren Johannsen i det ${ }^{1 / 2}$ mil nordligere liggende Silbersted med deres hustruer hører til de ligefremme, vennesæle, oplyste folk, som vi danske desværre træffe altfor få af her i Sydslesvig; men med des større trofasthed og taknemlighed vil hine undtagelser ihukommes af mangen dansk soldat: fra den hojeste officer til den menige mand". - (Johannsen var Gustav J.' far).

\section{Pastor Augustiny som forfatter.}

Som næunt hedder hans første bog "De hellige tider $\mathrm{i}$ den kristne kirke«. Skønt kun 68 små sider er den indholdsrig. Første del er 17 digte af forf. selv: Morgen-, aften-, jule-, påskeosv.-sange, endende med en sang til reformationsfesten. Kømnesange med klar evangelisk tone, enkelte kunde vel endog godt optages i salmebogen; på én gang historisk-skildrende de hellige tildragelser og trohjærtig-ydmyge $i$ deres af tak bårne tone; dertil formsikre, lydefri i verset. - Anden del er en prosa-gennemgang af kirkeårets helligdage med redegørelse for deres. gamle latinske navne og årsagerne til disse, meget oplysende - 
med skam og tak at sige - selv for en gammel præst.") - Og denne bog er skrevet af en 34årig huslærer nede i Svans! Der kan altså komme noget godt også fra det Nazareth.

Hans næste bog er, som også før nævnt, "Fire prædikener« fra Olandstiden (1842), udgivne for at skaffe lidt penge til "Einfriedigung des Olander Kirchhofes". Vi har jo hørt, hvordan stormfloder kunde delægge alt derovre. - Det er atter ægte evangelisk tale, hvor frelserens gærning kommer til sin fulde ret og ære. Ingen rationalistisk afsvækkelse. Dertil klar disposition og inddeling af temaets tanker; af de prædikener, der er lette at huske. Også prægede af, at forf. er godt hjemme i sin Bibel; han har ikke, som ofte nu, glemt den gamle bog over de mange ny, der nu tager vor tid.

For at give en prøve på hans poetiske ævne aftrykkes her det første vers af det digt (til Oland-menighed), hvormed han indleder den lille bog:

Nimm deines Hirten kleine Gabe,

Die Liebe weiht sie, Oland, dir;

Ich gebe was und wie ich's habe

Zum freudlichen Gedenken hier,

Wenn nicht in Deinem Kirchlein mehr

Ich rufe: kommt zu Jesu her!

Derefter følger i 1852 "Forsøg til en Chronik over Hollingsted«. Den viser for det forste et ganske afgjort dansk syn på Sønderjyllands historie, idet forfatteren aftrykker hele 7 vidnesbyrd til gunst for hertugdommets danske tilhørsforhold, statsretligt, til kongeriget. Det 6. er Allens Danmarkshistories, og det 7. selve kong Frederik 7.'s afvisende svar til den slesvigholst. deputation i marts 1848.

Iøvrigt indeholder bogen en mængde oplysninger om sognets historie, både dets sagnprægede og dets sikre efterretninger i form af forrige præsters dagbogsoptegnelser. Endvidere kir-

4) F. eks. fastesundagens: Invocavit i følge salme 91,15. Reminiscere efter salme 25,6. Cantate efter Zak. 2,10. Judica efter salme 43,1. Og påsketiden: Quasimodogeniti 1. Peter 2,2 . Misericordia Salme 89,2 . Jubilate Salme 66,2 . osv. 
ke- og skoleforhold, geografiske og økonomiske tilstande, præsterækken siden reformationen, og egne oplevelser i 3 ånskrigen, hvor også feltprovst Hammerich og feltpræsterne Høyer Møller og Blume nævnes; men intet om, at han har været presset til, endsige givet efter for oprørernes krav om underskrift på et ulydigheds-dokument imod regeringen.

Endelig er der som en art overgang til hans næste bog prøver på hans kendskab og kærlighed til plattysk, bl. a. en lille samtale mellem Rasmus og Carsten angående oproret, hvor Rasmus repræsenterer Angler-plat [Augustinys eget barndomssprog] og Carsten Hollingsted-plat, som præsten altså hurtigt har tilegnet sig. Sprogforskellen hindrer ikke de to mænd af det jævne folk i at se ens på oprøret o: de ser bægge som forfatteren selv. -

Denne næste bog - og sidste, her skal omtales - er på plattysk helt igennem og af meget broget indhold; har jo som nævnt den hyggelige titel "Achtern Aben". Pastor Augustiny har holdt af dette jævne, grammatikfri sprog. Han roser det som et rigt tungemål med mangfoldighed i udtrykkene, især for jævne menneskers oplevelser og livserfaringer; det er levende på den måde netop, at det er vidnesbyrdet om og aflejringen af dagliglivets mangehånde, store og små iagttagelser og resultater. Tillige fuld af billeder og fri for indblandinger fra andre sprog. Altså ganske det samme, som vi siger om det jydsk, der har et årtusind eller to bag sig, mens vort skriftsprog jo egentlig kun er Ł-5 hundrede år gammelt. Følgelig gælder det om dem bægge, at, vil vi kende den jævne mand, skal vi bede ham holde sig til dette modersmåal og lytte til, hvad han har at sige os i det.

Pastor Augustiny har brugt det som barn, lyttet til det som voxen og brugt det for ligesom yderligere at give den jævne mand lejlighed til at finde sig selv og give sig selv, træde beskedent og dog klogt frem i disse ham så passende hjemlige klæder. Augustiny er da en folkelig mand som sin ældre samtidige deroppe på den jydske hede, Steen Steensen Blicher. 
Hvad indhold har han da stabt ind i eller fundet fuldfardigt $\mathrm{i}$ denne form? Såre meget, men intet, som vilde passe dårligt til formen. Ikke højere poesi og ikke dybere filosofi, men desmere af det på det jævne.

Der er små kristelige digte, enfoldige morgen- og aftenbønner, og fromme tanker som disse:

Uns Herrgåt hädd uns all so lew, Dat he sin Sæhn vom Himmel gew. De ut Erbarmen, fri sien Blod För unse Schuld un Sünn vergot, En Stä bereitet hädd för all.

Tum jüngsten Dag siet Adams Fall, kåmt man to me, ick will ju geben, Seggt uns' Herrchrist, en ewig Leben, un jeder schall mien Herrlichkeit

Denn seh'n, de an mi globen deiht.

Der er moraliserende digte med godslig snært til de selvfølende og pralende. Han kan her minde om både den nordslesvigske Nicolaj Andersen og især om Vejlemanden Anton Berntsen. Han har f. ex. oversat Gellerts om "Hans, der rejste udenlands«. Eller fortalt om hertugen og Hollingstedbonden Johann Jöns, der bringer et læs hø til hertugen, indbydes af denne til overdådig middag med fine vine, taffelmusik og sæde på kostbare stole, men får samtidig at vide, at sådant gæstebud kan naturligvis en bonde ikke mode op med. Johann indbyder dog dristigt hertugen og lader de fine gæster sidde på solidt fyldte kornsække, spise den fedeste steg og skylle den ned med masser af godtøl, samt lader alle gårdens køer, heste, får og geder slippe ud i gården, hvor de leverer øredøvende musik! Hertugen er overvældet og forsikrer: De Bur is de glücklichste Minsch in de Welt.

Eller historien om faderen, der lover en kostbar ring til den af hans 3 sønner, der over den bedste gerning. Den ene får betroet en mands penge og gods uden bevis for modtagelse. Han leverer det dog alt uskadt tilbage. "Du var ærlig, men heller ikke mer«. Den anden redder et barn fra at drukne. "Det var 
din pligt«. Den tredje redder sin fjende, der er falden i søvn på randen af en stejl strandbred. "Godt! Man skal gøre vel imod sin fjende".

Der er også som nævnt digte oversat fra svensk, så Augustiny har øjensynlig været ret vel hjemme i læsning af vore nordiske mål. - Og han er så sund i sit syn på ungdom, så han kan digte en helt munter sang til de unge at danse efter:

Så laver han gåder, sagtens adskilligt, han har hørt i mindre heldig form, og nu giver bedre ikladning både på vers og $i$ prosa:

Da kommt en Mann ut Agypten,

He hädd en Råck an von hunnert Flecken;

He hädd en knækern Angesioh,

He hädd en Kamm un kämm sich nich.

De Prester un sin Dågter, de Kæster un sin Fru gong' $n$ spazeren un foun' $n$ ' en Vageln'ess. mit veer Eier in. Jehwerrer von se nehm een, un een wi blew in't Ness. - Wosück gong dat an?

Men navnlig har han et utal af ordsprog. Han kan her minde om præsten Feilberg, der på samme tid og få mil nordligere gik og samlede folkelig visdom og gamle skikke, uden at de sagtens har kendt noget til hinanden. Nogen har vi helt tilsvarende; andre fornøjer os som helt ny: Wenn't regent op de Prester, so dröpt et op de Kææster. Wenn de Müss satt büsst, is dat Mehl bidder. Wenn de Brannwien is in de Mann, is de Verstand in de Kann. Wi häm nog en Hähn mit en anner to plækken. Dat regent bi Sonnenschien, da kommt en Snieder in de Himmel. Man mutt de Tehren na de Nähren stellen. Ost un West tohus is best. Väl Geschrei awer wenig Woll, sä de Düwel, da schraper he en Swien. Lawen is ehrlich, awen holen is bebeswerlich. -

Men kan det more os sådan at se vore egne vindeverrer, er det dog nok så interessant at møde noget nyt: He hädd studert bet an de Hals, awer in de Kopp is nix herin kamen. He is in Rom wess un hädd de Pap nich sehn. He sprickt vom groten Christoffer un hädd de lüdje noch nich sehn. Binnen krank un 
butten blank. Häst du Geld, büss du lew, du magst wesen krumm oder schew. Gottesdeenst geiht vær Herrendeenst. He geiht lewer to Mark as to Kark. -

Lad så de to sidste gælde den mand, vi har lært at kende, men i en ændret mening: Pastor Augustiny gik både til mark og kark, o: både til sit folk og sin Gud; tjente tro både sin jordiske herre og sin himmelske Gud.

Aabenraa, den 25. Januar 1943.

N. A. Jensen. 